\title{
Topical Solution/Concentrate for Oromucosal Solution Dosage Form
}

National Cancer Institute

\section{Source}

National Cancer Institute. Topical Solution/Concentrate for Oromucosal Solution Dosage

Form. NCl Thesaurus. Code C149417.

Liquid preparation consisting of a solution intended for cutaneous use or intended to be diluted in the specified liquid to obtain an oromucosal solution. 